\title{
USE OF ALTERNATIVE MEDICINE BY PATIENTS UNDERGOING CARDIAC SURGERY
}

Eric H. Liu, BA

Leslie M. Turner, BA

Susan X. Lin, MA

Lorissa Klaus, MD

Lorraine Y. Choi, BA

Jery Whitworth, RN, CCP

Windsor Ting, MD

Mehmet C. Oz, MD
Objective: Complementary and alternative medicine may influence cardiac surgical care by inducing coagulopathies and interacting with perioperative medications. We evaluated the significance of complementary and alternative medicine use in an acutely ill cardiac surgical population and assessed the willingness of patients to reveal these activities to their physicians and surgeons.

Methods: A total of 376 consecutive patients undergoing preoperative or postoperative cardiothoracic surgical evaluations at an urban academic medical center were approached to complete a survey regarding use and attitudes toward complementary and alternative medicine. All surveys were administered and collected between March and May 1998.

Results: Completion rate was $70 \%(\mathrm{n}=263)$. Respondents were predominantly male $(72 \%)$, white $(76 \%)$, and well educated $(59 \%)$. The overall rate of complementary and alternative medicine use was $75 \%$, but excluding prayer and vitamins, which are often not considered complementary and alternative medicine therapies, the rate was $44 \%$. There was no correlation between the use of complementary and alternative medicine and the parameters of gender, age, race, or education level. Only 17\% responded that they had discussed complementary and alternative medicine with their physicians, and $48 \%$ responded that they did not want to discuss the topic at all.

Conclusions: Complementary and alternative medicine is used as frequently in patients undergoing cardiac surgery, as in the general population. Physicians and surgeons should be aware that patients have no inherent predisposition toward or against using complementary and alternative medicine, but that they are unlikely to volunteer their experience with it. The unwillingness of patients to discuss complementary and alternative medicine with physicians has serious implications for their safety, especially in acute care situations. (J Thorac Cardiovasc Surg 2000;120:335-41)
A tention from the news media, alternative medicine service providers, government agencies, and the medical community has caused the use rate of alterna-

From the College of Physicians and Surgeons, Columbia University, Department of Complementary Medicine Services, Presbyterian Hospital, School of Public Health, Columbia University, Department of Surgery, College of Physicians and Surgeons, Columbia University, New York, NY.

Received for publication Jan 5, 2000; revisions requested Feb 18, 2000; revisions received March 13, 2000; accepted for publication March 15, 2000.

Address for correspondence: Eric H. Liu, 60 Haven Ave, 11F, New York, NY 10032 (E-mail: ehl7@ columbia.edu).

Address for reprints: Mehmet C. Oz, MD, 177 Fort Washington Ave, New York, NY 10032.

Copyright (C) 2000 by The American Association for Thoracic Surgery

$0022-5223 / 2000 \$ 12.00+0 \quad \mathbf{1 2 / 1 / 1 0 7 3 3 9}$

doi:10.1067/mtc.2000.107339 tive medicine by the general US population to increase from $33.8 \%$ in 1990 to $42.1 \%$ in $1997 .{ }^{1}$ This trend supports the argument that alternative or complementary medicine, defined as health interventions not generally available at US hospitals or taught widely in medical schools, has gained greater acceptance by the general population as a means of maintaining health.

However, these data do not reflect the use of alternative medicine in those patients who have serious medical conditions requiring major procedures or hospitalization, a population of individuals health care providers most commonly deal with. Several new studies have addressed this question, with up to $20 \%$ of oncology patients, ${ }^{2} 50 \%$ of family practice patients, ${ }^{3} 28 \%$ of breast cancer patients, ${ }^{4}$ $51 \%$ of inflammatory bowel disease patients, ${ }^{5}$ and $38 \%$ of head and neck cancer patients ${ }^{6}$ using some sort of complementary or alternative therapy. Assessments of com- 
Table I. Demographic profile of the 262 patients included in the study

\begin{tabular}{|c|c|c|}
\hline & $N$ & $\%$ \\
\hline \multicolumn{3}{|l|}{ Age (y) } \\
\hline $18-39$ & 21 & 8 \\
\hline $40-64$ & 106 & 40.6 \\
\hline$>65$ & 134 & 51.3 \\
\hline \multicolumn{3}{|l|}{ Sex } \\
\hline Male & 187 & 71.6 \\
\hline Female & 74 & 28.4 \\
\hline \multicolumn{3}{|l|}{ Race } \\
\hline White & 195 & 75.9 \\
\hline African American & 17 & 6.6 \\
\hline Hispanic & 16 & 6.2 \\
\hline Native American & 15 & 5.7 \\
\hline Asian/Pacific Islander & 10 & 3.9 \\
\hline Other & 4 & 1.6 \\
\hline \multicolumn{3}{|l|}{ Marital status } \\
\hline Single & 23 & 8.9 \\
\hline Married & 186 & 72.1 \\
\hline Divorced & 12 & 4.7 \\
\hline Widowed & 33 & 12.8 \\
\hline Other & 4 & 1.6 \\
\hline \multicolumn{3}{|l|}{ Education } \\
\hline Grade school/middle school & 17 & 6.5 \\
\hline High school/equivalent & 83 & 31.9 \\
\hline College/technical & 90 & 34.6 \\
\hline More than college & 64 & 24.6 \\
\hline
\end{tabular}

plementary medicine use in specific disease processes are particularly important for the health care provider, as alternative medical therapies can have a direct effect on proper conventional medical care.

The use rate of a prominent patient population, those undergoing cardiac surgery, has not been reported. To address this shortcoming, we surveyed the use of complementary medical therapies in patients undergoing cardiac surgery in an urban hospital. In addition, patients were queried about their attitudes toward healing, their opinions of the use of alternative medicine in a complementary role with conventional medicine, and their willingness to discuss the topic with their physicians or surgeons. These results will help health care providers better understand the role of complementary medicine in the care of their patients, as well as its relationship to the patients' attitudes toward health.

\section{Methods}

The survey was conducted in the waiting area of the Cardiothoracic Surgery Service of Columbia-Presbyterian Medical Center in New York City, from March to May 1998. The questionnaire was voluntary, anonymous, and took approximately 10 minutes to complete. Eligible subjects included all English-speaking and writing adults.
The survey consists of 4 parts: demographic information, attitudes toward healing, patterns of use of complementary/alternative medicine modalities, and attitudes toward complementary/alternative medicine and willingness to discuss the topic with a physician (Fig 1). Demographic information included age, gender, marital status, level of education, and ethnic background. Questions about attitudes toward healing were rated on a scale of 1 to 10, with 1 representing "Not at all" and 10 "A great deal." The following questions were asked: "How much can you do yourself to help your body heal better, faster, or more completely?" "How much do you believe mental attitude about a medical procedure affects the outcome of the procedure?"

The next section assessed the patients' experience with complementary/alternative medicine therapies. To assess the experiences with complementary/alternative medicine techniques, we provided a list of modalities and the patients were asked, "Have you ever used any of the following?" The option of yes or no followed each modality. The modalities included in the list were as follows:

$\begin{array}{ll}\text { Acupuncture } & \text { Massage therapy } \\ \text { Ayurveda } & \text { Meditation/relaxation } \\ \text { Biofeedback } & \text { Naturopathy } \\ \text { Chelation } & \text { Nutritional therapy } \\ \text { Chiropractic } & \text { Prayer/pastoral counseling } \\ \text { Energy healing } & \text { Qi gong } \\ \text { Guided imagery } & \text { Reflexology } \\ \text { Herbs } & \text { Tai chi } \\ \text { Homeopathy } & \text { Vitamins } \\ \text { Hypnosis } & \text { Yoga } \\ & \text { Other }\end{array}$

The next section examined the attitudes toward complementary/alternative medicine and the attitudes toward discussing the topic with a physician. The following questions, again rated on a scale from 1 to 10 , were asked: "Do you believe any of the above therapies would assist conventional medical treatments in fighting illness?" "Do you believe any of the above therapies would promote general health and wellness?"

To assess prevalence of dialogue with their physicians on the topic of complementary/alternative medicine, as well as desire to create dialogue, we asked the patients, "Have you discussed any of the above therapies with your medical doctor/surgeon?" Again, they had the option of answering yes or no. A follow-up question, again with the option of yes or no, included, "If no, would you like your medical doctor/surgeon to discuss the above therapies with you?"

At the conclusion of the survey, patients were asked to place the survey in a box located in the waiting area.

\section{Results}

A total of 376 consecutive patients were approached with the questionnaire and 263 responded (response rate 70\%). The patients were largely married, white men over the age of 65 years who had at least a high school education (Table I). Use was quite common in these patients, with $75 \%$ having 
Table II. Pattern of complementary/alternative modality use by patients

\begin{tabular}{lrc}
\hline \multicolumn{1}{c}{ Therapy } & $N$ & $\%$ \\
\hline Vitamin & 141 & 53.6 \\
Prayer & 95 & 36.1 \\
Nutritional therapy & 45 & 17.1 \\
Massage & 30 & 11.4 \\
Chiropractic & 30 & 11.4 \\
Meditation & 30 & 11.4 \\
Herbs & 26 & 9.9 \\
Acupuncture & 11 & 4.2 \\
Homeopathy & 8 & 3.0 \\
Reflexology & 6 & 2.3 \\
Hypnosis & 6 & 2.3 \\
Yoga & 6 & 2.3 \\
Other & 6 & 2.3 \\
Energy & 4 & 1.5 \\
Tai chi & 4 & 1.5 \\
Aromatherapy & 4 & 1.5 \\
Imagery & 3 & 1.1 \\
Acupressure & 3 & 1.1 \\
Biofeedback & 2 & 0.8 \\
Chelation & 2 & 0.8 \\
Naturopathy & 1 & 0.4 \\
Qi gong & 1 & 0.4 \\
Ayurveda & 0 & 0 \\
\hline
\end{tabular}

used 1 of the 21 alternative treatments in the past 12 months. Of the choices, vitamins and prayer were the most popular, with use rates of $54 \%$ and $36 \%$, respectively (Table II). However, excluding prayer and vitamins, the use rate was only $43.7 \%$, similar to the $42.1 \%$ reported for the general population. The most popular therapies other than vitamins and prayer were nutritional therapy (17\%), massage $(11 \%)$, chiropractic (11\%), meditation (11\%), and herbs $(9.9 \%)$. When using these therapies, most patients reported having used two or more therapies $(57.1 \%)$.

Among the demographic variables measured (gender, age, race, marital status, or education), no significant correlation could be found with the use of alternative medicine. Among the different therapies, vitamins tended to be used mostly by older persons, more educated persons (college or higher), and white persons, and prayer and meditation tended to be used more by nonwhite persons (Table III).

When asked about their attitudes toward healing, patients believed that they had a role in their healing process (on a scale 1-10, 8.2 users, 8.0 non-users) and that mental attitude did have an effect on the outcome of medical procedures (8.7 users, 8.2 non-users), with comparable responses between users and non-users of alternative medicine. However, responses to the effectiveness of alternative therapies with conventional medicine in fighting illness (6.9 users, 4.9 non-users)
Table III. Differences found between users and nonusers of some therapies on some demographic variables

\begin{tabular}{|c|c|c|}
\hline & Users (\%) & Non-users (\%) \\
\hline \multicolumn{3}{|c|}{ Vitamin use by age group } \\
\hline $18-39(y)$ & 28.6 & 71.4 \\
\hline 40-64 (y) & 51.9 & 48.1 \\
\hline$>65(\mathrm{y})$ & 59.4 & 40.6 \\
\hline \multicolumn{3}{|l|}{$P=.027$} \\
\hline \multicolumn{3}{|c|}{ Vitamin use by racial group } \\
\hline White & 58.8 & 41.2 \\
\hline Nonwhite & 35.5 & 64.5 \\
\hline \multicolumn{3}{|l|}{$P=.001$} \\
\hline \multicolumn{3}{|c|}{ Prayer by racial group } \\
\hline White & 31.9 & 68.1 \\
\hline Nonwhite & 51.6 & 48.4 \\
\hline \multicolumn{3}{|l|}{$P=.005$} \\
\hline \multicolumn{3}{|c|}{ Meditation use by racial group } \\
\hline White & 8.8 & 91.2 \\
\hline Nonwhite & 17.7 & 82.3 \\
\hline \multicolumn{3}{|l|}{$P=.50$} \\
\hline \multicolumn{3}{|c|}{ Vitamin use by education group } \\
\hline College or more & 59.7 & 40.3 \\
\hline$<$ College & 44.4 & 55.6 \\
\hline$P=.017$ & & \\
\hline
\end{tabular}

Table IV. Patients' attitudes toward mental outlook and health and the effectiveness of complementary/alternative medicine

\begin{tabular}{lllllll}
\hline & \multicolumn{2}{c}{ Users } & & \multicolumn{3}{c}{ Non-users } \\
\cline { 2 - 3 } & Mean & $S D$ & & Mean & $S D$ & P value \\
\hline Q. 1 & 8.17 & 2.07 & & 7.98 & 2.12 & .531 \\
Q. 2 & 8.71 & 1.90 & & 8.25 & 2.03 & .098 \\
Q.3 & 6.9 & 2.52 & & 4.94 & 2.62 & .000 \\
Q.4 & 7.3 & 2.35 & & 5.6 & 2.5 & .000 \\
\hline
\end{tabular}

On a scale of 1-10, where $1=$ "Not at all" and 10= "A great deal"

Q.1 How much can you do yourself to help your body heal better, faster, or more completely?

Q. 2 How much do you believe mental attitude about a medical procedure affects outcome?

Q. 3 Do you believe any of the above therapies would assist conventional medical treatments in fighting illness?

Q. 4 Do you believe any of the above therapies would promote general health and wellness?

and the effectiveness in general health (7.3 users, 5.5 non-users) trended toward less effectiveness (Table IV). No differences in responses were based on demographic variables.

When queried about the patient-physician discussion of alternative medicine use, most patients had not discussed the topic of alternative medicine with their 
We are very interested in your feelings about healing and your health. Please fill out this questionnaire to the best of your ability. There are no wrong answers. Check the boxes and circle the numbers that correspond to your answer. All information will be kept strictly confidential. Thank you very much for help.

(1) Date

(2) Age (3) $\square$ Male

$\square$ Female

(4) Marital Status

$\square$ Single $\quad \square$ Married $\square$ Divo
$\square$ Widowed $\quad \square$ Other
$\square$ Grade/Middle School
$\square$ High School/Equivalency
$\square$ College or Technical
$\square$ More than college

(6) Ethnic Background

$\begin{array}{ll}\square \text { African-American } & \square \text { Asian } \\ \square \text { Caucasian } \square \text { Hispanic } & \square \text { Native American } \\ \square \text { Pacific Islander } & \square \text { Other }\end{array}$

On a scale of $1-10(1=$ Not at all, $10=$ A Great Deal $)$, please circle a number which best represents your feelings/attitudes to each question.

(7) How much can you do yourself to help your body heal better, faster, or more completely?

$$
\text { (Not at All) (A Great Deal) }
$$

(8) How much do you believe mental attitude about a medical procedure affects the outcome of the procedure?

$$
\begin{array}{cccccccccc}
1 & 2 & 3 & 4 & 5 & 6 & 7 & 8 & 9 & 10 \\
\text { (Not at All) } & & & & & & & \text { (A Great Deal) }
\end{array}
$$

(9) Have you ever used any of the following therapies over the last 12 months? Circle yes or no to all that apply.

$\begin{array}{ll}\text { Therapy } & \\ \text { Acupressure } & \text { Yes/No } \\ \text { Acupuncture } & \text { Yes/No } \\ \text { Aromatherapy } & \text { Yes/No } \\ \text { Ayurveda } & \text { Yes/No } \\ \text { Biofeedback } & \text { Yes/No } \\ \text { Chelation } & \text { Yes/No } \\ \text { Chiropractor } & \text { Yes/No } \\ \text { Energy Healing } & \text { Yes/No } \\ \text { Guided Imagery } & \text { Yes/No } \\ \text { Herbs } & \text { Yes/No } \\ \text { Homeopathy } & \text { Yes/No } \\ \text { Hypnosis } & \text { Yes/No }\end{array}$

$\begin{array}{ll}\text { Massage Therapy } & \text { Yes/No } \\ \text { Meditation } & \text { Yes/No } \\ \text { Naturopathy } & \text { Yes/No } \\ \text { Diet Modification } & \text { Yes/No } \\ \text { Prayer/Pastoral Counseling } & \text { Yes/No } \\ \text { Qi Gong } & \text { Yes/No } \\ \text { Reflexology } & \text { Yes/No } \\ \text { Tai Chi } & \text { Yes/No } \\ \text { Vitamins } & \text { Yes/No } \\ \text { Yoga } & \text { Yes/No } \\ \text { Other } & \end{array}$

Fig 1. Questionnaire distributed to patients. 


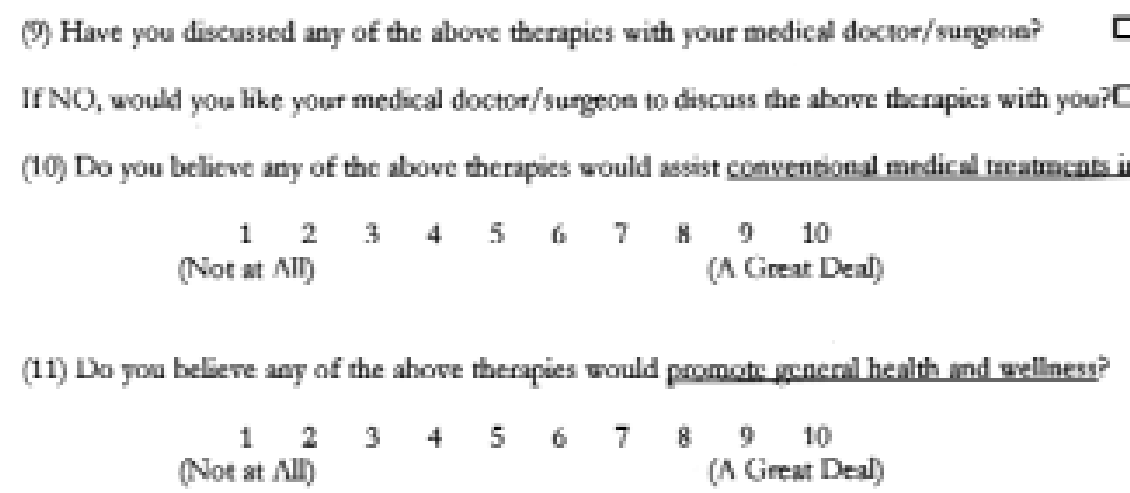

Fig 1. Cont'd Questionnaire distributed to patients.

physicians or surgeons. Only 17\% responded that they had discussed the topic. Of the $83 \%$ who had not discussed the topic, only $36 \%$ responded that they would like to discuss the topic with their physicians and $48 \%$ responded that they did not want to discuss the topic; $16 \%$ did not respond to this question.

\section{Discussion}

The results of this study demonstrate that the use of techniques other than conventional medicine is quite high $(75 \%)$ in patients undergoing cardiac surgery. However, when prayer and vitamins are excluded from the analysis, as they are not always considered "complementary medicine," use by this population of patients is similar to that of the general population-43.7\% (surgical population) versus $42.1 \%$ (general population). Moreover, the selection of therapies is also similar. In the general population study, relaxation techniques, herbal medicine, massage, and chiropractic therapies were the most popular; among patients with cardiac disease, nutrition, massage, herbs, chiropractic, and meditation were most often used.

The similar utilization rates show that patients with cardiac disease accept alternative medicine as readily as the general population. One may have believed that patients with major medical conditions, who are already accessing medical resources at a higher rate, might choose to access alternative medicine more freely. Alternatively, one could postulate that the diseased state of these patients is a result of self-neglect and might correlate with a lower predicted use rate. Neither appears to be the case.

Since our patients believe that mental attitude is an important element of healing, addition of alternative therapies as an empowering tool would appear rational. The observation that non-users tended to have less faith in the role of a positive mental attitude would suggest that patients who use complementary medicine may be more inclined to take an active role in their healing. Unfortunately, we are unable to determine whether patients originally had a more positive outlook and therefore chose to use complementary therapies or whether the complementary therapies increased confidence in the role of mental outlook. If the latter is true, then health care providers may be able to integrate complementary therapies into the care program to help modify a patient's belief system and improve a patient's mental outlook.

Although both users and non-users responded positively toward mental attitude and its benefit toward healing, respondents were clearly divided on their belief of the effectiveness of complementary therapies in conjunction with conventional medicine. Non-users were less convinced that complementary therapies are effective. Although we cannot determine whether patients initially believed in complementary medicine, or whether their experience with complementary medicine convinced them of its utility, patients who use complementary medicine nonetheless believe that the therapies are effective.

Relevant to the question of why patients choose complementary therapies is the question of who is choosing. Previous studies of the general population have exhibited similar demographics among users of complementary medicine-individuals 15 to 20 or 50 to 69 years old, living in the western United States, and having a higher education level than those who did not use 
Table V. Common products and herbs that may affect surgical outcomes

\begin{tabular}{ll}
\hline \multicolumn{1}{c}{ Product } & \multicolumn{1}{c}{ Effects } \\
\hline Coagulation & \\
Dehydroepiandrosterone (DHEA) & Interacts with plasminogen activator inhibitor and tissue plasminogen activator \\
Eicosapentaenoic acid (EPA) & Decreases platelet aggregation \\
Fish oils & Increases fibrinolysis \\
Garlic & Inhibits platelet aggregation \\
Onion & Inhibits platelet aggregation \\
Vitamin E & Inhibits platelet aggregation \\
Feverfew & Interacts with warfarin \\
Gingko biloba & Interacts with warfarin \\
Coenzyme $Q_{10}$ & Interacts with warfarin \\
Ginger & Interacts with warfarin \\
Ginseng & Interacts with warfarin \\
St John's Wort & Interacts with warfarin \\
Drug interactions & \\
Hawthorn berry & Interacts with digoxin \\
Kyushin & Interacts with digoxin \\
Licorice & Interacts with digoxin \\
Plantain & Interacts with digoxin \\
Uzara root & Interacts with digoxin \\
Ginseng & Interacts with digoxin \\
St John's Wort & Interacts with digoxin, warfarin, oral contraceptives, cyclosporin, antiviral drugs \\
Iron & Affects bioavailability \\
Hemodynamics & \\
Caffeine & Hypertension \\
\hline
\end{tabular}

alternative therapies. ${ }^{7,8}$ However, in our study we found no significant difference in use of complementary medicine on the basis of age, sex, education level, or ethnicity. This fact may reflect biases in our patient population. Unlike the general population, 59\% of patients surveyed were educated at a college or technical school level or higher, and all subjects were only Englishspeaking. With an inadequate number of patients educated at a lower level, we are unable to determine whether patients with cardiac disease truly differ from the general population.

The prevalence of alternative medicine among medically ill patients must serve as a warning sign to health care providers. These patients are often receiving prescription medications, putting them at risk for potential adverse interactions with herbs or high-dose vitamins. Several case reports have highlighted the dangers of herbal medicine. The herb danshen has been shown to cause further anticoagulation in patients receiving warfarin. ${ }^{9}$ Moreover, the toxic effects of the herbs or the impurity of the herb preparation might be the cause of serious medical diseases. For example, a case of cardiomyopathy was reportedly linked to the use of an herb for eczema. ${ }^{10}$ Given that the use of alternative medicine can have direct effects on the care of patients, the fact that patients are so reluctant to report their use of alternative therapies forces health care providers to be especially vigilant in pursuing this aspect when taking a history. In the general population, only $38.5 \%$ of patients reported alternative therapy use to their physicians. Among patients with cardiac disease, only $17.1 \%$ discussed alternative therapy use, with over half of the patients not desiring to discuss the topic with their physicians. This important difference in reporting alternative therapy use demonstrates that patients with serious medical illnesses still consider alternative medicine and conventional medicine separate and distinct. Moreover, patients do not recognize that alternative therapies can have dangerous toxic effects, and physicians must be aware of these adverse effects. In the course of a medical interview, a physician can quickly inquire about herb or alternative therapy use during an evaluation of the patient's current medications.

Some popular herbs can have significant effects on the outcomes of surgical procedures, particularly in the areas of coagulation, drug interactions, and hemodynamics (Table V). ${ }^{11}$ Regarding coagulation, several herbs have been shown either to directly affect bleeding time or to interact with anticoagulation medications. For example, dehydroepiandrosterone (DHEA) is known to affect plasminogen activator inhibitor and tissue plasminogen activator $^{12}$; eicosapentaenoic acid (EPA) and fish oils are known to affect platelet aggregation ${ }^{13}$ and fibrinolysis. ${ }^{14}$ Garlic and onion are known to inhibit platelet aggrega- 
tion $^{15,16}$; vitamin $\mathrm{E}$ has effects on platelet function as well. ${ }^{17,18}$ Many products, including feverfew, garlic, gingko biloba, coenzyme $\mathrm{Q}_{10}$, ginger, and ginseng interact with warfarin. ${ }^{11,19}$ With regard to drug interactions, products such as hawthorn berry, kyushin, licorice, plantain, uzara root, and ginseng are known to interact with digoxin. ${ }^{11}$ Iron, an extremely common supplement and medicine, has effects on bioavailability. ${ }^{20}$ St John's Wort, the popular herb used in depression, may have significant effects on medications such as warfarin, digoxin, oral contraceptives, cyclosporin, and antiviral drugs. ${ }^{21,22}$ Last, the surgeon should be aware that common supplements, such as caffeine, can have significant effects on hemodynamics. ${ }^{23}$ Because of the possible effects on surgical outcomes, the American Society of Anesthesiologists has recommended that all herbal therapy be stopped 2 weeks before surgery. ${ }^{24}$

Patients who have medical conditions use complementary/alternative therapies as often as the general population, demonstrating that this population is not biased in its decision to use complementary medicine. Although our study is limited to patients undergoing cardiothoracic surgery, these data are consistent with findings in other patient populations and may reflect the same attitudes of patients with other serious disease processes; future studies should be undertaken to better characterize the use in other patient populations. As new research expands our understanding of the benefits and dangers of alternative/complementary medicine, physicians and patients must be open in their discussion of complementary/alternative medicine use.

We thank Dr Eric Rose, Dr Craig Smith, and Dr Niloo Edwards for their support in this work. We also thank Lidia Nieves, Geri Messer, Sarah Shaines, and all the members in the Departments of Cardiothoracic Surgery and Complementary Medicine Services for their help in administering this study.

\section{REFERENCES}

1. Eisenberg DM, Davis RB, Ettner SL, Appel S, Wilkey S, Van Rompay M, et al. Trends in alternative medicine use in the United States, 1990-1997. JAMA 1998;280:1569-75.

2. Risberg T, Lund E, Wist E, Dahl O, Sundstrøm S, Andersen OK, et al. The use of non-proven therapy among patients treated in Norwegian oncological departments: a cross-sectional national multicentre study. Eur J Cancer 1995;31A:1785-9.

3. Elder NC, Gillcrist A, Minz R. Use of alternative health care by family practice patients. Arch Fam Med 1997;6:181-4.

4. Burstein HJ, Gelber S, Guadagnoli E, Weeks JC. Use of alternative medicine by women with early-stage breast cancer. N Engl J Med 1999;340:1733-9.

5. Rawsthorne P, Shanahan F, Cronin NC, Anton PA, Lofberg R, et al. An international survey of the use and attitudes regarding alternative medicine by patients with inflammatory bowel disease. Am J Gastroenterol 1999;94:1298-303.
6. Warrick PD, Irish JC, Morningstar M, Gilbert R, Brown D, Gullane P. Use of alternative medicine among patients with head and neck cancer. Arch Otolaryngol Head Neck Surg 1999;25:573-9.

7. Eisenberg DM, Kessler RC, Foster C, Norlock FE, Calkins DR, Delbanco TL. Unconventional medicine in the United States: prevalence, costs and patterns of use. $\mathrm{N}$ Engl $\mathrm{J}$ Med 1993;328:246-52.

8. Paramore LC. Use of alternative therapies: estimates from the 1994 Robert Wood Johnson Foundation National Access to Care Survey. J Pain Symptom Manage 1997;13:83-9.

9. Yu CM, Chan JC, Sanderson JE. Chinese herbs and warfarin potentiation by “danshen.” J Intern Med 1997;241:337-9.

10. Ferguson JE, Chalmers RJ, Rowlands DJ. Reversible dilated cardiomyopathy following treatment of atopic eczema with Chinese herbal medicine. Br J Dermatol 1997;136:592-3.

11. Miller LG. Herbal medicinals: selected clinical considerations focusing on known or potential drug-herb interactions. Arch Intern Med 1998;158:2200-11.

12. Beer NA, Jakubowicz DJ, Matt DW, Beer RM, Nestler JE. Dehydroepiandrosterone reduces plasma plasminogen activator inhibitor type 1 and tissue plasminogen activator antigen in men. Am J Med Sci 1996;311:205-10.

13. Kinsella JE. Effects of polyunsaturated fatty acids on factors related to cardiovascular disease. Am J Cardiol 1987;60:23G-32G.

14. Sakamoto N, Nishiike T, Iguchi H, Sakamoto K. Effects of eicosapentaenoic acid intake on plasma fibrinolytic and coagulation activity by using physical load in the young. Nutrition 2000;16:11-4

15. Apitz-Castro R, Cabrera S, Cruz MR, Ledezma E, Jain MK. Effects of garlic extract and of three pure components isolated from it on human platelet aggregation, arachidonate metabolism, release reaction and platelet ultrastructure. Thromb Res 1983;32:155-69.

16. Vanderhoek JY, Makheja AN, Bailey JM. Inhibition of fatty acid oxygenases by onion and garlic oils: evidence for the mechanism by which these oils inhibit platelet aggregation. Biochem Pharmacol 1980;29:3169-73.

17. Jandak J, Steiner M, Richardson PD. Alpha-tocopherol, an effective inhibitor of platelet adhesion. Blood 1989;73:141-9.

18. Freedman JE, Farhat JH, Loscalzo J, Keaney JF Jr. Alpha-tocopherol inhibits aggregation of human platelets by a protein kinase C-dependent mechanism. Circulation 1996;94:2434-40.

19. Spigset O. Reduced effect of warfarin caused by ubidecarenone. Lancet 1994;344:1372-3.

20. Campbell NR, Hasinoff BB. Iron supplements: a common cause of drug interactions. Br J Clin Pharmacol 1991;31:251-5.

21. Ernst E. Second thoughts about safety of St. John's Wort. Lancet 1999;354:2014-6.

22. Department of Health, United Kingdom. Important interactions between St John's Wort (Hypericum perforatum) preparations and prescribed medicines. Available at: http://www.doh.gov.uk/ cmo/cmo00_04.htm. Accessed March 4, 2000.

23. Nurminen ML, Niittynen L, Korpela R, Vapaatalo H. Coffee, caffeine and blood pressure: a critical review. Eur J Clin Nutr 1999;53:831-9.

24. Leak JA. Herbal medicines: What do we need to know? Available at http://www.asahq.org/newsletter/2000/02-00/herbal0200.html. Accessed March 9, 2000. 